\title{
A Study of the Learning Strategies Used by Secondary School and University Students of English in Spain
}

\author{
Ignacio M. Palacios Martínez \\ Universidad de Santiago de Compostela
}

\begin{abstract}
The aim of this paper is to identify the type and range of the language learning strategies used by Spanish secondary and university learners in their study of English. For the collection of data, eighty students and twenty five teachers of both educational levels were interviewed. The data collected were statistically processed through the Chi-square test. The results obtained indicate that (a) the majority of the students were conscious of their use of strategies, (b) cognitive strategies were by far the type of strategies most commonly reported, (c) university students made use, although not significantly, of a higher number and a wider variety of strategies than secondary school pupils, (d) the majority of the teachers were not aware of their students' use of strategies. The paper concludes by making a series of pedagogical recommendations that can be gathered from the previous work.
\end{abstract}

\section{Introduction}

In the last two decades or so, an important shift has taken place in the field of second language teaching and learning research as scholars have focused mainly on learner's individual factors, leaving aside their earlier and only interest in teaching methods and techniques. Gardner and Lambert, Gardner, Spolsky and Oller showed the importance of attitude and motivation in their studies. Chastain investigated the influence of the so-called affective factors. Schumann referred to the function of social factors. Zampogna, Gentile, Papalia and Silber, Tucker, Hamayan and Genesee, Bialystok and Frohlich were mostly concerned with learner's cognitive variables. Krashen and Rosansky pointed out the influence of the age factor. As far as learning strategies are concerned, research has demonstrated, firstly, the existence of a series of mechanisms and tactics learners put into operation in the language learning process and, secondly, the important implications of these strategies for language teaching as they seem to enhance students' own learning. 
This article ${ }^{1}$ reports the main findings of a study designed to identify the type and range of strategies used by secondary school and university students of English in Spain, and to determine teachers' familiarity with the students' previous use of these strategies.

\section{Review of Literature}

Learning strategies are defined by Oxford and Crookall as "steps taken by the learner to aid the acquisition, storage and retrieval of information" (404). Rubin and Wenden in their definition of strategies point out that they usually refer to specific actions or techniques which may or may not be observed. According to them, some of the strategies are consciously used, and can be modified and learned. In addition, it is generally agreed that strategies are present in both informal and academic settings. However, most of the research in this area up to the present date has been focused on the second language classroom in particular and little attention has been paid to foreign language environments.

Several typologies (Ellis; O'Malley et al.; Oxford; Rubin; Wenden; Willing) have been formulated for the description and classification of language learning strategies, such as linguistic, non-linguistic, direct, indirect, cognitive, metacognitive, social, communicative, memory, compensation, and so on. For the purposes of this paper, that of Oxford will be followed, drawing a general division between direct and indirect strategies. Direct strategies are those which are concerned with the target language in a wide variety of tasks and situations, and may be subdivided into those strategies used for recalling, storing and retrieving information (memory strategies), those which serve to understand, practise and produce the language (cognitive strategies) and, finally, those strategies used by learners in spite of the difficulties they find (compensation strategies). ${ }^{2}$ Indirect strategies, on the other hand, deal with the management of learning and consist of metacognitive strategies for monitoring learning, affective strategies for regulating personal emotions, and social strategies for learning and interacting with others.

The research carried out to investigate the field of language learning strategies has made use of different methods. Interviews (Cohen and Hosenfeld; Nainam, Frohlich, Stern and Todesco; O'Malley et al.; Wenden) and questionnaires (Bialystok; Ehrman and Oxford; Oxford and Nyikos; Ramírez) seem to be the most commonly used instruments. However, on some occasions, observation ( $O$ ' Malley et al.; Rubin, “Study of Cognitive Processes in Second Language Learning"), diaries (Rubin, "What the "Good Language Learner' Can Teach Us"; Tyacke and Mendelsohn) and lists (Stern) have also been employed. For limitations of space, reference will only be made to those language learning studies which are most closely connected with the aims of this paper.

O'Malley et al. set out to identify the type, range and frequency of the learning strategies used by 70 ESL students at beginning and intermediate levels in three high schools in Northern Virginia. The learners of Hispanic origin were interviewed in small groups of three to five. In addition, individual interviews were also carried out with twenty-two teachers. From the previous research, it was gathered that the learners were able to describe a wide range of learning strategies which could be classified into three main categories: metacognitive, cognitive and social mediating strategies. The results 
obtained also indicated that the number of strategies used by the learners correlated with the degree of difficulty of the learning task and, on the whole, students tended to use more cognitive than metacognitive strategies. Furthermore, it was also found that teachers in general were not very aware of their students' strategy use.

By means of a questionnaire, Bialystok surveyed the strategies used by high school students in their learning of French. The data collected showed as before that the use of strategies was governed by the nature of the task, and it also seemed to be directly related to the learners' attitude and not to language learning aptitude.

Ramírez also administered questionnaires to adolescents who were studying French in several New York schools. The information collected revealed that years of language study was an important variable affecting the use of learning strategies.

\section{Purpose}

The first purpose of this research was to investigate the students' degree of awareness in their use of language learning strategies and identify the range, type and frequency of the strategies used with particular language activities by a group of Spanish secondary school and university students in their learning of English. The second aim of this survey was to determine to what extent secondary school teachers and university lecturers of English were acquainted with the learners' use of strategies. Thirdly, we were also interested in finding out whether the interview could be considered as a valid and reliable instrument for the investigation of language learning strategies. Finally, the fourth aim of this work was to come up with a series of pedagogical implications that could be of special relevance for language teaching.

\section{Method}

\subsection{Subjects}

Interviews were carried out with 50 secondary school students, aged 14 to 20 , from six different high-schools located in urban and rural settings of Galicia, and with 30 English Philology students, aged 18 to 24, from the University of Santiago de Compostela. Secondary school students' command and knowledge of the language were not the same among all the students. Their levels varied from elementary to intermediate. In contrast, all the university students were advanced learners of English; for the majority of these, the language level can be described as being close to Cambridge Proficiency. ${ }^{3}$ Spanish was the mother tongue for $78 \%$ of the total number of respondents while Galician was limited to $22 \%$. A similar proportion was kept between male and female learners. All of them volunteered to be interviewed so they can be considered as a self-selected group. Furthermore, interviews were also conducted with 10 secondary school teachers and with 15 lecturers in charge of language courses at the University of Santiago. As before, the majority of them had Spanish as their mother tongue. Their teaching experience varied a 
considerable degree from one individual to another. It ranged from one year to over fifteen. On this occasion, sex was not taken into account as the number of male teachers was so restricted that comparisons between the two groups according to this factor would not have made much sense. As in the case of the students, they also offered themselves voluntarily to participate in the project.

\subsection{Materials}

Two data collection instruments were used in the study: a student interview form and a teacher interview form. Both interview guides were semi-structured and could be easily compared, as they followed a similar pattern as far as their content and format were concerned. Obviously, the wording of the questions was different to suit the interviewees. Students were asked about the strategies they used while teachers were asked about the strategies they observed their students using.

These interviews were divided into three main parts. The first section was a simple introduction explaining the purpose of the study. The second section, the central one, consisted of the elicitation from the subjects interviewed of the language learning strategies used with seven language activities: pronunciation, grammar, vocabulary, listening, reading, writing and oral expression. The last section was reserved for any further comments students wished to make or any questions they wanted to ask. The complete list of questions for each of these interviews is shown in the Appendix.

\subsection{Procedures}

The interviews with teachers and learners of the two educational levels were carried out in the Spring semesters of 1989 and 1990 . The average duration of these interviews was from 20 to 30 minutes. Spanish or Galician was used according to the subjects' preferred language of personal communication. First drafts were piloted with small groups of subjects to find out whether it was necessary to introduce any changes in the original plan and to see how far we could go along with the interview in the exploration of strategies. All the interviews were conducted individually, that is, on a one to one basis with the exception of those with English Philology lecturers, who were interviewed in groups of five. At that stage of the project, it was felt that interviewing the lecturers in groups of five could favour teachers' reflection upon their students' strategy use and would make the interaction more spontaneous and natural, especially when considering that the preceding interviews with their secondary school colleagues had been at times quite cold and had not provided much information. All the interviews with students were taped. Interviews with teachers were not recorded because most of the respondents explicitly said that they preferred not to be taped and, consequently, it was believed this might have put them on the defensive and bias the replies obtained. Some of the teachers at the end of the session said that before beginning it, they had certain reserves and false expectations about the general objectives of the interview; they thought it could be an implicit test on their teaching skills. 
The interviewers had in front of them a list of learning strategies drawn from the literature review (Oxford), to use, if necessary, as prompts with both teachers and learners. These prompts were intended to clarify terminology and to suggest possible alternatives when the level of interaction between interviewer and interviewee was really poor. The members of the interview team were specifically trained in the conduct of these interviews and were told to refer to this elicitation instrument as the last resort; we were aware of the fact that a continuous and systematic use of this kind could distort our findings.

Interviewers filled in an interview report form immediately after the interview had been completed. On these forms, the different types and number of learning strategies mentioned by the informants were annotated as carefully as possible together with other questions they considered worthwhile mentioning. To verify results, the report forms were later contrasted with the transcripts of the taped interviews and corrections were made when required. Several meetings were also held with the interviewers to clarify difficult issues and to make sure that the coding had been done in similar terms for all the interviews. In this way intercoder reliability was highly accomplished.

The data collected were statistically processed through the Chi-square test to determine whether there existed significant differences between the two groups of learners (Secondary and University students) on each type of learning strategy. ${ }^{4}$

\section{Results}

The majority of the interviewees appeared to be aware of their use of learning strategies and they were also able to verbalize them. In addition, the interview was a useful instrument to investigate the area of language learning strategies as it stimulated learners' reflection upon their learning process and the number of strategies reported was quite high. The fact that the interviewees constituted a self-selected group and that their attitudes towards this project were extremely positive could have also contributed to this.

A general division was first drawn between direct and indirect strategies. Direct strategies were subdivided further into cognitive, memory and compensation strategies, while indirect strategies were only subdivided into metacognitive strategies, as the other subtypes of strategies classified by the literature under this heading - affective and social strategies- did not occur in the data. Furthermore, each of these subgroups of strategies was considered to be integrated by other types of substrategies. Finally, all these subtypes may also appear in different forms. Repetition, for example, may be done individually, in chorus, in front of a mirror and with the aid of a tape-recorder.

On certain occasions, it was not easy to classify the type of substrategy being dealt with, as learners tended to report instances when several strategies were being used at the same time; on the other hand, some of the examples of strategies provided could at times be grouped under more than one single category, as described by Oxford. This may indicate that Oxford's classification system may require certain modifications and adjustments as certain categories at times overlap. The information collected indicated the existence of a total number of 469 mentions of different strategies which can be classified 
into 11 main strategies and 28 substrategies. The list of the strategies and substrategies identified are shown in table 1.

LEARNING STRATEGY IDENTIFIED: DESCRIPTION AND EXAMPLeS (Table 1)

\begin{tabular}{|l|l|}
\hline LEARNING STRATEGY TYPE & DESCRIPTION AND EXAMPLES \\
\hline I. DIRECr STRATEGY & \multicolumn{1}{|l|}{} \\
\hline A. Cognitive Strategies & $\begin{array}{l}\text { Repetition: repeating individually or in chorus what the } \\
\text { teacher and other students are saying, writing words several } \\
\text { times, reading a text aloud several times, practising } \\
\text { repeatedly in front of a mirror, recording one's voice to see } \\
\text { how it sounds, doing exercises several times. } \\
\text { Formally practising with sounds and writing systems: } \\
\text { writing the word in Spanish as it sounds in English. } \\
\text { Recombining: writing long sentences by putting together } \\
\text { known words or expressions. } \\
\text { Recognizing formulas and patterns: looking at models for a } \\
\text { writing task. }\end{array}$ \\
\hline $\begin{array}{l}\text { Receiving and sending } \\
\text { messages }\end{array}$ & $\begin{array}{l}\text { Using resources for receiving and sending messages: using } \\
\text { the dictionary, grammar and phonetics books. }\end{array}$ \\
\hline Analysing and reasoning & $\begin{array}{l}\text { Reasoning deductively: deriving hypotheses and making } \\
\text { generalisations by using rules the learner already knows or } \\
\text { by comparing examples. } \\
\text { Analysing expressions: breaking down a new sentence or } \\
\text { word into its component parts; paying attention to word- } \\
\text { order. } \\
\text { Analysing contrastively across languages: establishing } \\
\text { connections between English/Galician/Spanish, and between } \\
\text { English and other foreign languages. } \\
\text { Translating: before writing, thinking first in Spanish and } \\
\text { then translating into English. }\end{array}$ \\
\hline $\begin{array}{l}\text { Creating structure for input } \\
\text { and output }\end{array}$ & $\begin{array}{l}\text { Highlighting: emphasizing the most important points and } \\
\text { words to remember through highlighting, circling and } \\
\text { underlining. }\end{array}$ \\
\hline
\end{tabular}




\begin{tabular}{|c|c|}
\hline \multicolumn{2}{|l|}{ B. Memory Strategies } \\
\hline Creating mental linkages & $\begin{array}{l}\text { Associating new language information with familiar } \\
\text { concepts already in memory, using mnemonic devices. } \\
\text { Placing new words into a meaningful written or spoken } \\
\text { context. } \\
\text { Grouping words into semantic fields. }\end{array}$ \\
\hline Applying images and sounds & $\begin{array}{l}\text { Using imagery: associating words with pictures. } \\
\text { Representing sounds in memory: remembering words by } \\
\text { making auditory rather than visual representations of sounds } \\
\text { (remembering song titles and certain expressions with a } \\
\text { peculiar intonation). } \\
\text { Semantic mapping: making outlines and diagrams with key } \\
\text { concepts. }\end{array}$ \\
\hline \multicolumn{2}{|l|}{ C. Compensation strategies } \\
\hline Guessing intelligently & $\begin{array}{l}\text { Using linguistic clues: guessing the meaning of words in a } \\
\text { reading text, guessing what the speakers could be saying in } \\
\text { a particular situation. } \\
\text { Using other clues: illustrations and lay-out of text. }\end{array}$ \\
\hline \multicolumn{2}{|l|}{ II. INDIRECT STRATEGIES } \\
\hline \multicolumn{2}{|l|}{ A. Metacognitive Strategies } \\
\hline Centering your leaming & $\begin{array}{l}\text { Paying attention: deciding in advance to concentrate on the } \\
\text { main points (selective attention). }\end{array}$ \\
\hline $\begin{array}{l}\text { Arranging and planning } \\
\text { your learning }\end{array}$ & Organizing: preparing a language learning notebook. \\
\hline $\begin{array}{l}\text { Seeking practice } \\
\text { opportunities }\end{array}$ & $\begin{array}{l}\text { Listening to English records, trying to understand the lyrics. } \\
\text { Listening to the radio and watching satellite television. } \\
\text { Watching English films with subtitles in Spanish and } \\
\text { keeping record of new words. } \\
\text { Practising orally with other students of the class and with } \\
\text { other members of the family. } \\
\text { Looking for native-speakers in town. } \\
\text { Reading bilingual magazines, books, "readers," instructions } \\
\text { of electrical appliances, food ingredients, etc. } \\
\text { Writing to pen-friends. }\end{array}$ \\
\hline Evaluating your learning & Self-monitoring: learning from previous errors in writing. \\
\hline
\end{tabular}

In spite of the problems experienced on certain occasions in the tagging of the strategies students reported, it can be concluded that the vast majority of the students questioned tended to use a higher number of direct strategies than indirect strategies. As can be seen in table 2, cognitive strategies were by far the most commonly reported. 
LEARNING STRATEGIES USED BY BOTH SECONDARY SCHOOL AND UNIVERSITY STUDENTS OF ENGLISH (Table 2)

\begin{tabular}{|l|c|c|}
\hline \multicolumn{1}{|c|}{ TYPE OF LEARNING } & NUMBER OF MENTIONS & \% OF TOTAL \\
\hline A. Cognitive strategies & & \\
Repetition & 107 & 22.81 \\
Formally practising & 3 & 0.63 \\
Identifying formulas and & 12 & 2.55 \\
patterns & 14 & 2.98 \\
Analysing deductively & 16 & 3.41 \\
Analysing contrastively & 14 & 2.98 \\
Recombining & & \\
Using resources for & 26 & 5.54 \\
receiving and sending & 27 & 5.75 \\
messages & 6 & 1.27 \\
Translation & 225 & 47.97 \\
Highlighting & & \\
Total: & & \\
\hline B. Memory strategies & & \\
Creating mental linkages & & \\
and applying images and & & \\
sounds & & \\
\hline C. Compensation strategies & & \\
Using linguistic and non- & & 0.85 \\
linguistic clues & & 0.21 \\
\hline D. Metacognitive strategies & & 16.41 \\
Seeking opportunities to & & \\
practise & & \\
Selected attention & & \\
Planning for a language task & & \\
Learning from errors & & \\
Total: & & \\
\hline
\end{tabular}

Repetition, creating mental images, applying sounds and pictures, translation, using linguistic and non-linguistic clues, working with the dictionary and, lastly, seeking for opportunities to practise were the types of strategies which obtained the highest number 
of mentions. It should be pointed out at this stage that prompting was required on only 15 occasions and was chiefly restricted to the questions in which the students were asked about the strategies they used for the learning of grammar and for the development of their listening skills. When the two groups of learners considered in the study are compared according to their strategy use, the figures indicate that university students, generally speaking, employ proportionately a higher number and a wider range of strategies than secondary school pupils.

Cognitive, Memory, Compensation and Metacognitive Strategies USED BY SECONDARY SCHOOL AND UNIVERSITY STUDENTS OF ENGLISH (Table 3)

\begin{tabular}{|c|c|c|c|c|c|c|c|c|c|c|c|c|}
\hline \multirow[t]{2}{*}{ LEARNING STRATEGY } & \multicolumn{4}{|c|}{ SECONDARY SCHOOL } & \multicolumn{4}{|c|}{ UNIVERSITY } & \multicolumn{4}{|c|}{ TOTAL } \\
\hline & $\mathbf{N}$ & $\%$ & $\mathbf{M}$ & $\%$ & $\mathbf{N}$ & $\%$ & $\mathbf{M}$ & $\%$ & $\mathbf{N}$ & $\%$ & $\mathbf{M}$ & $\%$ \\
\hline Cognitive & 42 & 84 & 105 & 38.5 & 30 & 100 & 120 & 61.2 & 72 & 90 & 225 & 48 \\
\hline Memory & 31 & 62 & 57 & 20.9 & 15 & 50 & 20 & 10.2 & 46 & 76.2 & 77 & 16.4 \\
\hline Compensation & 33 & 66 & 62 & 22.7 & 14 & 46.6 & 16 & 8.2 & 78 & 58.7 & 40 & 16.6 \\
\hline Metacognition & 34 & 68 & 49 & 17.9 & 27 & 90 & 40 & 20.4 & 61 & 76.2 & 89 & 19 \\
\hline
\end{tabular}

$\mathrm{N}$ : number of subjects

M: Mentions

In spite of this, it should be added that, according to the probability frequency obtained for this item through the Chi-square test, the differences between the two groups are not statistically significant at the .05 level; in other words, from a statistical perspective, the differences that occur in terms of number of strategies used by the two groups are not relevant. In contrast, as can be seen in table 4 , significant differences are found with regard to the nature of those strategies. Thus, statistical differences are identified when comparing the values corresponding to the cognitive, memory and compensation strategies. This does not apply in the case of metacognitive strategies since the level of significance is higher than the .05 value generally considered by most scholars in quantitative studies as the lowest rate of significance between groups.

COMPARISON OF FREQUENCIES ObTAINED IN THE TWO GROUPS FOR THE Different TYPES OF LeARNing Strategies ACCORDing to $\mathrm{X}^{2}$ (Table 4)

\begin{tabular}{|l|c|c|c|c|}
\hline \multicolumn{1}{|c|}{ LEARNING } & $\begin{array}{c}\text { SECONDARY } \\
\text { SCHOOL } \\
\text { Mentions }\end{array}$ & Mentions & $\mathrm{X}$ & SIGNIFICANCE \\
\hline Cognitive & 105 & 120 & 24.067 & .000 \\
\hline Memory & 57 & 20 & 4.365 & .037 \\
\hline Compensation & 62 & 16 & 9.603 & .002 \\
\hline
\end{tabular}




\begin{tabular}{|l|c|c|c|c|}
\hline Metacognitive & 49 & 40 & 2.104 & .147 \\
\hline Total & 273 & 196 & 3.685 & .055 \\
\hline
\end{tabular}

$(\mathrm{p}>.05 ; \mathrm{df}=1)$

The data collected also showed that the number of learning strategies reported by students varied depending on the type of learning activity, as presented in table 5 . The largest figures of strategies were reported in pronunciation, vocabulary learning and the understanding of reading texts. In contrast, listening inference and oral expression obtained the lowest number of mentions. This may be due to two factors: first, the degree of difficulty associated with these learning activities; there is a tendency on the students' part to consider listening and speaking as more difficult skills than those involved in the learning of vocabulary and in the decoding of written texts (Palacios); secondly, the type of environment where the students are learning English, which is a foreign language setting; while Spanish students can learn vocabulary items and practise pronunciation on their own without the teacher's help, this does not apply to aural and oral practice, opportunities for which mainly occur in the classroom.

LEARNING STRATEGIES USED BY SPANISH SECONDARY SCHOOL AND UNIVERSITY STUDENTS OF ENGLISH FOR DIFFERENT LEARNING ACTIVITIES (Table 5)

\begin{tabular}{|c|c|c|c|c|c|c|c|c|c|c|c|c|}
\hline \multirow[t]{2}{*}{ LEARNING ACTIVTTY } & \multicolumn{4}{|c|}{ SECONDARY SCHOOL } & \multicolumn{4}{|c|}{ UNIVERSITY } & \multicolumn{4}{|c|}{ TOTAL } \\
\hline & $N$ & $\%$ & $\mathbf{M}$ & $\%$ & $\mathbf{N}$ & $\%$ & $\mathbf{M}$ & $\%$ & $\mathbf{N}$ & $\%$ & $\mathbf{M}$ & $\%$ \\
\hline Pronunciation & 23 & 46 & 37 & 13.5 & 22 & 73.3 & 37 & 18.9 & 45 & 56.2 & 74 & 15.8 \\
\hline Grammar learning & 25 & 50 & 39 & 14.3 & 17 & 56.6 & 24 & 12.2 & 42 & 52.5 & 63 & 13.4 \\
\hline Vocabulary learning & 36 & 72 & 54 & 19.8 & 20 & 66.6 & 36 & 18.4 & 56 & 70 & 90 & 19.2 \\
\hline Listening inference & 17 & 34 & 22 & 8.1 & 14 & 46.6 & 23 & 11.8 & 31 & 38.7 & 45 & 9.6 \\
\hline Oral expression & 22 & 44 & 29 & 10.6 & 19 & 63.3 & 27 & 13.6 & 41 & 51.2 & 56 & 12 \\
\hline Reading texts & 38 & 76 & 59 & 21.6 & 18 & 60 & 25 & 12.7 & 56 & 70 & 84 & 17.9 \\
\hline Writing tasks & 25 & 50 & 33 & 12.1 & 18 & 60 & 24 & 12.2 & 43 & 53.7 & 57 & 12.1 \\
\hline
\end{tabular}

$\mathrm{N}$ : number of subjects

M: mentions

Furthermore, when the figures collected for the two groups are compared, the only significant differences found are those corresponding to the strategies learners report using when learning pronunciation. In this case, university students mention proportionately a considerably higher number of strategies than their peers at secondary school; this surely explains the Chi-square and significance values obtained for this item, considering the fact that the former group was formed by only 30 subjects and the latter by 50 (see table 6). The differences found between the two groups with regard to the pronunciation strategies may be related to, at least, two variables: first, the purpose of learning at each level, and 
secondly, the existence of a specific Phonetics course as part of the English university programme. At the secondary level students chiefly aim at being able to communicate and making themselves understood in the foreign language; this means that pronunciation is important as long as they can express themselves and be understood. At university, however, students are not only satisfied with the achievement of the previous objectives; as they are specializing in English, they also want to sound as close to native speakers as possible, hence the high degree of importance allocated to pronunciation.

COMPARISON OF FREQUENCIES OBTAINED IN THE TWO GROUPS FOR THE

DIFFERENT TYPES OF STRATEGIES ASSOCIATED WITH LEARNING ACTIVITIES ACCORDING TO $\mathrm{X}^{2}$ (Table 6)

\begin{tabular}{|l|c|c|c|c|}
\hline \multicolumn{1}{|c|}{$\begin{array}{l}\text { LEARNING } \\
\text { StrATEGY }\end{array}$} & $\begin{array}{c}\text { SECONDARY } \\
\text { SCHOOL } \\
\text { Mentions }\end{array}$ & Mentions & UNIVRSITY & SIGNIFICANCE \\
\hline Pronunciation & 37 & 37 & 4.933 & .026 \\
\hline Grammar learning & 39 & 24 & .010 & .922 \\
\hline $\begin{array}{l}\text { Vocabulary } \\
\text { learning }\end{array}$ & 54 & 36 & .240 & .624 \\
\hline Listening inference & 22 & 23 & 3.557 & .059 \\
\hline Oral expression & 29 & 27 & 2.743 & .098 \\
\hline Reading texts & 59 & 25 & 2.146 & .143 \\
\hline Writing tasks & 33 & 24 & .516 & .473 \\
\hline
\end{tabular}

$(\mathrm{p}<.05 ; \mathrm{df}=1)$

As for the teachers' perception of students' strategy use, the information collected indicated that most of the teachers interviewed at both secondary and university levels were not fully aware of the students' use of learning strategies. The majority of them were not even acquainted with this area in language learning. Clarification of questions and prompting were more frequently required than with the students. As shown in table 7, teachers were not able to mention a high number and a wide range of strategies as they only referred to 14 substrategies used by their students. This may indicate that foreign language teachers in general devote little time and attention to observing what is going on in the learning process; restrictions and requirements imposed by the educational system may make teachers concentrate chiefly on the teaching of an official syllabus, disregarding other important aspects of the teaching and learning processes.

The strategies associated with vocabulary learning and the reading and writing of texts were the ones most commonly mentioned. Secondary school teachers overall were in a better position to identify more and a wider variety of learning strategies than university lecturers. This may be justified by the fact that language groups in Spain at the tertiary level tend to be rather large and, as a result, lecturers cannot follow students' progress as 
closely as in high schools. Furthermore, some innovations recently introduced by the Spanish educational administration in the secondary school curriculum emphasize the role and importance of strategies in the learning process. Quite possibly, secondary school teachers of English may also have been influenced by this recommendation.

Teachers' Perception of Students' Strategy Use (Table 7)

\begin{tabular}{|l|l|}
\hline \multicolumn{1}{|c|}{ LEARNING ACTIVITY } & \multicolumn{1}{c|}{ TYPE OF STRATEGY } \\
\hline Pronunciation & Repetition \\
\hline Grammar learning & $\begin{array}{l}\text { Analysing contrastively across languages } \\
\text { Using translation }\end{array}$ \\
\hline Vocabulary learning & $\begin{array}{l}\text { Using a vocabulary note-book } \\
\text { Checking the dictionary } \\
\text { Associating words with sounds } \\
\text { Analysing deductively }\end{array}$ \\
\hline Listening inference & Selected attention \\
\hline Oral expression & $\begin{array}{l}\text { Planning and rehearsing } \\
\text { Using translation } \\
\text { Memory }\end{array}$ \\
\hline Reading & Using linguistic and non-linguistic clues \\
\hline Writing & $\begin{array}{l}\text { Translating } \\
\text { Recombining } \\
\text { Using formulas } \\
\text { Writing to pen-friends }\end{array}$ \\
\hline
\end{tabular}

\section{Conclusions}

The main findings of this study indicated that the majority of the secondary school and university students interviewed were able to identify and report the use of a wide range of learning strategies. This means that most learners at an intermediate and advanced level of English proficiency in a foreign language environment use strategies. University students reported a higher number of strategies than high school learners, although the total differences found between the two groups were not statistically significant at a .05 level. In contrast, the figures obtained were indicative in the case of the cognitive, memory, compensation and pronunciation strategies. Spanish students of English at the university mentioned more cognitive and pronunciation strategies whereas the opposite trend was identified with memory and compensation strategies. Secondly, cognitive strategies outnumbered by far the rest of the strategies collected. Thirdly, no instances of affective and social strategies were reported by our subjects. Fourthly, the use, number and choice of strategies varied according to the language activity carried out by the learner. Although the research instruments utilized in this survey were not exactly the same as those used in 
previous studies, these findings only in part confirm the results of past research (Bialystok; O'Malley et al., Ramírez) conducted in second language environments; this, consequently, may question their validity for foreign language settings. Fifthly, the group interview and, particularly, the individual one turned out to be a useful method for the investigation of strategies since learners' self-reflection on their learning process was successfully achieved and the amount of information collected was higher than expected. Finally, this research revealed that Spanish secondary school and university teachers were not fully aware or acquainted with the field of language learning strategies and, therefore, one may think that strategy training was not introduced into their teaching as an ordinary and well thought-out practice.

Several pedagogical implications for language teaching can be gathered from this research. Firstly, the great variety of mechanisms and strategies mentioned by the learners in this study give us insights into the difficulties students come across when learning a foreign language, i.e. keeping new words in memory, getting acquainted with a new grammatical system, decoding and guessing the meaning of unknown words, strong need for language practice. It also provides valuable and interesting information on the techniques learners resort to when trying to overcome those problems, i.e. repetition, formal practice, creating mental linkages, analysing deductively and contrastively. Secondly, everything seems to indicate that this factor plays a central role in the learning of a foreign language and, therefore, teachers should have a full understanding of the different strategies used by their students for learning it as this will shed light on important areas of their teaching. Thirdly, it is reasonable to think that students' autonomy and selfdirection should be promoted if teachers make them reflect upon their learning and train them in learning how to learn.

The provisional character of our findings and the pedagogical conclusions gathered from them reveal the need for conducting further research into this area to verify results and obtain a deeper understanding. It would be extremely interesting to investigate several variables (sex, age, learning style, motivation, social background), which may affect secondary school and university students' choice of strategies together with the effects that strategy training programmes may have on learners in the long and short term. Although Oxford's classification was quite useful and practical, it is still necessary to clarify certain labels, expand and modify others with the purpose of being more accurate and avoiding unnecessary overlapping.

Comparative studies in the use of strategies in the L1 and L2 could also be illuminating and practical. Furthermore, additional research instruments, such as diaries, questionnaires and observation could also be implemented to complete the data collected through interviews. Studies based upon bigger and more representative samples of Spanish students and teachers of English could also make important contributions and would serve to confirm and validate the results and conclusions reached in this work. 


\section{Notes}

1. A preliminary version of this paper was presented at the conference of the Spanish Association of Anglo-American Studies, Valladolid, December 1992.

2. Memory and compensation strategies could also be taken as cognitive in nature since they also draw on cognition. However, for the purpose of this study, we decided to keep Oxford's original classification without introducing any changes. Quite possibly, Oxford preferred to classify these three types under different categories because of their high frequency and their relevance in the language learning process.

3. Elementary includes real and false beginners as well as those students who have already done a course of English of about 120 hours. Advanced students are those who have already passed the Cambridge First Certificate Exam or the RSA (Royal Society of Arts), level II, and who are getting prepared for the Cambridge Proficiency Exam and/or the RSA, level III. Intermediate students are in between; they are in their third or fourth year of serious study of the language and they have done between 150 and 600 hours of English.

4. The author wishes to acknowledge the collaboration of José Luis Simón from the Santiago University Computer Centre in the statistical processing of the data.

\section{Works Cited}

Bialystok, Ellen. "The Role of Conscious Strategies in Second Language Proficiency." Modern Language Journal 65 (1981): 24-35.

and Maria Frohlich, M. "Variables of Classroom Achievement in Second Language Learning." Modern Language Journal 42.7 (1978): 327-36.

Chastain, Kenneth. "Affective and Ability Factors in Second Language Acquisition." Language Learning 25.1 (1975): 153-61.

Cohen, Andrew D. and Carol Hosenfeld. "Some Uses of Mentalistic Data in Second Language Acquisition." Language Learning 31 (1981): 285-313.

Ehrman, Madeline and Rebecca Oxford, R. "Adult Language Learning Styles and Strategies in an Intensive Training Setting.” Modern Language Journal 74.3 (1990): 311-27.

Ellis, Rod. Understanding Second Language Acquisition. Oxford: Oxford UP, 1985.

Gardner, Robert C. Social Psychology and Second Language Learning: The Role of Attitudes and Motivation. London: Arnold, 1985.

. "Attitudes and Motivation." Annual Review of Applied Linguistics 9 (1988): 135-48. and Wallace E. Lambert. Attitudes and Motivation in Second Language Learning. Rowley: Newbury House, 1972.

Krashen, Stephen D. "Lateralization, Language Learning and the Critical Period: Some New Evidence." Language Learning 23 (1976): 63-74.

. Principles and Practice in Second Language Acquisition. London: Prentice Hall International, 1982.

Naiman, Neil, Maria Frohlich, H. H. Stern and Angela Todesco. The Good Language Learner. Research in Education Series 7. Toronto: The Modern Language Centre, Ontario Institute for Studies in Education, 1978.

Oller, John. W, Jr. "Attitude Variables in Second Language Learning." Viewpoints on English as a Second Language. Ed. Maria Burt, Heidi Dulay and Mary Finocchiaro. New York: Regents, 1977. $172-84$. 
O'Malley, Michael J., Anna Uhl Chamot, Gloria Stewner-Manzanares, Lisa Küpper and Rocco P. Russo. "Learning Strategies Used by Beginning and Intermediate ESL Students." Language Learning 35.1 (1985): 21-46.

. "Learning Strategy Applications with Students of English as a Second Language." TESOL Quarterly 19.3 (1985): 557-84.

Oxford, Rebecca. Language Learning Strategies: What Every Teacher Should Know. New York: Newbury House/Harper and Row, 1990. , and David Crookall. "Research on Language Leaming Strategies: Methods, Findings and Instructional Issues.” Modern Language Journal 73.4 (1989): 404-19. and Martha Nyikos. "Variables Affecting the Choice of Language Learning Strategies by University Students.” Modern Language Journal 73.3 (1989): 291-300.

Palacios Martínez, Ignacio M. La enseñanza del inglés en España a debate. Santiago de Compostela: Servicio de Publicaciones de la Universidad, 1994.

Ramírez, Arnulfo G."Language Learning Strategies Used by Adolescents Studying French in New York Schools.” Foreign Language Annals 19.2 (1986): 131-41.

Rosansky, Ellen. "The Critical Period for the Acquisition of Language: Some Cognitive Developmental Considerations.” Working Papers on Bilingualism 6 (1975): 93-100.

Rubin, Joan. "What the 'Good Language Learner' Can Teach Us." TESOL Quarterly 9 (1975): 41-51.

. "Study of Cognitive Processes in Second Language Learning." Applied Linguistics 11.2 (1981): 118-31. and Anita Wenden. Learner Strategies in Language Learning. Englewood Cliffs: Prentice Hall, 1987.

Schumann, John H. "Affective Factors and the Problem of Age in Second Language Acquisition." Language Learning 25.2 (1975): 209-35.

Spolsky, Bernard. “Attitudinal Aspects of Second Language Learning." Language Learning 29.3-4 (1969): 271-83.

Stern, H.H. "What Can We Learn from the Good Language Learner?" Canadian Modern Language Review/La Revue Canadienne des Langues Vivantes 30 (1974): 304-18.

Tucker, G. Richard, Else Hamayan and Fred Genesee. "Affective, Cognitive and Social Factors in Second Language Acquisition." Canadian Modern Language Review/La Revue Canadienne des Langues Vivantes 32.3 (1976): 214-26.

Tyacke, Marian, and David Mendelsohn. "Student Needs: Cognitive as well as Communicative." TESL Canada Journal. Special Issue 1 (1986): 171-83.

Wenden, Anita. “Helping Language Leamers Think about Learning.” ELT Journal 40 (1986): 3-12.

"What Do Second-Language Learners Know about their Language Learning? A Second Look at Retrospective Accounts." Applied Linguistics 7.2 (1986): 186-205.

Willing, Kenneth. "Learning Strategies as Information Management: Some Definitions for a Theory of Learning Strategies." Prospect 3.2 (1988): 139-55.

Zampogna, Joseph, Ronald J. Gentile, Anthony Papalia and Gordon R. Silber. "Relationships between Learning Styles and Learning Environments in Selected Secondary Modern Language Classes." Modern Language Journal 60.8 (1976): 443-48. 


\section{Appendix}

\section{Student's interview form}

Hi! How are you? Well, we would like to ask you some questions with regard to your personal experience in the learning of English. Your name will be kept secret and confidential and we just want to remind you that this is not a test or any other thing of the kind.

Could we ask you some personal questions for our file?

1. How old are you?

2. Which form/year are you in?

3. What language(s) do you speak at home?

4. When did you start learning English?

5. How long have you studied English?

If you think a little bit now about your study of English, could you tell us whether you have acquired or developed any strategies, study skills, "tricks" that you consider useful and positive in your learning of English?

6. When learning pronunciation, for example, reading a text aloud:

7. When learning grammar, for example, learning rules:

8. When learning new words (vocabulary), for example, repeating the new vocabulary items several times:

9. When developing your ability to listen to English, for example, listening to records:

10. When learning how to speak English, for example, speaking to oneself:

11. When learning how to read and understand what you read, for example, reading comics and books on your own:

12. When learning how to write in English, for example, imitating models: 
13. Are there any others you would like to mention?

Thank you for your help!

Teacher's interview form

The teachers' interview form was exactly the same as the one used with the students. The only significant change occurred in the introductory section. That of the teachers' read as follows:

This interview is concerned with the techniques, "tricks," learning strategies and study skills used by your students and that you will presumably have observed in your daily practice. It is possible that you may consider some of them as irrelevant or negative whereas others might be the opposite.

Could we ask you some personal questions for our file?

1. What is your mother tongue?

2. How long have you been teaching English?

3. Could you make a brief description of your current teaching situation, number of students,

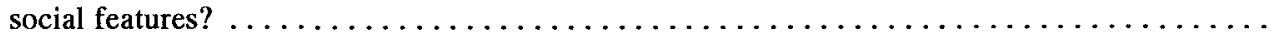

We will refer to different aspects related to the study of English and we will ask you to make a brief comment about the "tricks" or strategies employed by your pupils/students, etc. 